\title{
Efficacy of Coir Waste Compost and Urea at Different Levels on the Incidence of Sheath Blight of Rice
}

\author{
A. Sudha ${ }^{1 *}$, M. Senthilkumar ${ }^{2}$ and M. Vijayakumar ${ }^{3}$ \\ ${ }^{1}$ Department of Plant Pathology, Krishi Vigyan Kendra, Tamil Nadu Agricultural University, \\ Coimbatore, Salem district 636 203, Tamil Nadu, India \\ ${ }^{2}$ Department Agricultural Entomology, KVK Salem, Tamil Nadu Agricultural University, \\ Coimbatore, Tamil Nadu, India \\ ${ }^{3}$ Department of Agronomy, KVK Salem, Tamil Nadu Agricultural University, \\ Coimbatore, Tamil Nadu, India \\ *Corresponding author
}

A B S T R A C T

\begin{tabular}{|l|}
\hline Ke y w o r d s \\
L. connatus, \\
P. sajor- caju, \\
Coir waste, Urea, \\
Phosphorus, \\
Potassium, \\
Rhizoctonia solani. \\
\hline Article Info \\
\hline Accepted: \\
14 July 2017 \\
Available Online: \\
10 September 2017
\end{tabular}

Keywords

L. connatus,

Rhizoctonia solani.

Accepted:

Available Online:

September 2017
Lentinus connatus treated coir waste and urea at all levels significantly reduced the intensity of sheath blight, when compared with Plerotus sajorcaju. The treatments coir waste compost (L connatus) @18.5 t + urea @60 $\mathrm{kg} \mathrm{N} / \mathrm{ha}$ and composted coir waste (L. connatus) @15.5 t/ha + urea@60 $\mathrm{kg} \mathrm{N} /$ ha were found superior and significantly reduced the intensity of sheath blight (Gr. 3.00 and 3.52), compared to the existing fertilizer recommendation of $12.5 \mathrm{t}$ composted $+120 \mathrm{~kg} \mathrm{~N} / \mathrm{ha}$, where maximum disease intensity of Gr. 9.75 (sheath blight). The similar trend was also observed with $P$. sajor - caju. The above said best treatments also significantly reduced the disease intensity of sheath blight (Gr. 5.60 and 6.20). The earlier treatments not significantly reduced the disease intensity and on par with existing recommendation.

\section{Introduction}

In India, vast quantities of renewable agro and agro-industrial wastes are generated every year (Madan et al., 1987). More than half of the total produce from the land remains unused as wastes (Zadrazil, 1984). The abundant availability of these crop residues, the problems associated with its disposal, the associated environmental pollution problem and the physio-chemical characteristics of these materials attracted the attention of technologists in finding productive use of these crop residues.

The current boom in inorganic fertilizer prices and low availability of organic manures, limit the use of these viable source of nutrients in agriculture.

There have been many reports of studies on the bioconversion of lignocellulosic materials 
into a potential biomanure (Anderson et al., 1971; Zadrazil, 1975; Beg et al., 1986).

Efficient degradation of complex lignocellulosic wastes by Pleurotus spp. largely depends upon the synergistic action of extracellular enzymes like cellulases and lignases. These enzymes have been reported to narrow down the $\mathrm{C}$ : $\mathrm{N}$ ratio in various organic residues, indicating the better rate of lignocellulosic degradation (Sheeba et al., 1999; Singh and Griensven, 2000). Hence, soil application of such a degraded crop residues improves the nutritional status of the soil and suppresses soil borne pathogens (Rajan, 1980; Sheela, 1992).

In a search for an efficient biodegrader for the production of high quality biomanure, the present study was undertaken to probe the potentially of a new mushroom fungus viz., Lentinus connatus Berk, isolated from the dead woods of cashew (Lakshmanan, 2002), on comparison with existing biodegrader.

\section{Materials and Methods}

\section{Preparation of substrates for composting}

The substrates viz., paddy straw, sugarcane trash and sugarcane bagasse were chopped off 5 to $10 \mathrm{~cm}$ length. The substrate coir waste was used without chopping. They were solar dried for 5 - 6 h. Enough water was added to make it sufficiently moist (40 - 50\%). The moisture held in substrate was calculated by gravity method (Piper, 1966).

\section{Method of composting}

Heap method of composting described by Manickam et al., 1980) was followed. For composting $20 \mathrm{~kg}$ of moist substrate, $20 \mathrm{~g}$ fungal culture ( $L$. connatus / P. sajor caju) and $100 \mathrm{~g}$ urea were used. Two $\mathrm{kg}$ of substrate was spread uniformly $(75 \times 45 \mathrm{~cm})$ in a shaded place and $4 \mathrm{~g}$ of fungal culture ( $L$. connatus / P. sajor caju) was sprinkled over it. This was to be alternated with $2 \mathrm{~kg}$ of substrate and $20 \mathrm{~g}$ of urea. The alternate layers of substrate + culture and substrate + urea were stacked upto the height of $1 \mathrm{~m}$. Substrate only with L. connatus / P. sajorcaju was also maintained for comparison. The heap was allowed to degrade for a month. For each substrate / commonly grown rice cultivar ADT - 36, was sown in peat trays $(10 \times 20 \times 40$ $\mathrm{cm})$. Four weeks after germination, the seedlings were transplanted to $10 \mathrm{~cm}$ dia earthen clay pots filled with $4 \mathrm{~kg}$ of clay soil @ 3 seedlings per pot. Before transplanting, $50 \%$ of the total inorganic nitrogen and $100 \%$ of the total $\mathrm{P}_{2} \mathrm{O}_{5}, \mathrm{~K}_{2} \mathrm{O}$ and coir waste composted by L. connatus / P. sajor-caju, were applied at basal separately.

On $45^{\text {th }}$ and $60^{\text {th }}$ day after transplanting, the remaining $50 \%$ of total inorganic nitrogen was applied in two split doses. Three replicated pots for each fertilizer dose / composted coir waste ( $L$ connatus / P. sajorcaju), were maintained in a randomized complete black design.

\section{Treatments details}

\section{Fertilizer dose (ha)}

T1: $12.5 \mathrm{t}$ compost $+120 \mathrm{~kg} \mathrm{~N}+38 \mathrm{~kg} \mathrm{P}_{2} \mathrm{O}_{5}$ $+38 \mathrm{~kg} \mathrm{~K}_{2} \mathrm{O}$

T2: $12.5 \mathrm{t}$ compost $+90 \mathrm{~kg} \mathrm{~N}+38 \mathrm{~kg} \mathrm{P}_{2} \mathrm{O}_{5}+$ $38 \mathrm{~kg} \mathrm{~K}{ }_{2} \mathrm{O}$

T3: $12.5 \mathrm{t}$ compost $+60 \mathrm{~kg} \mathrm{~N}+38 \mathrm{~kg} \mathrm{P}_{2} \mathrm{O}_{5}+$ $38 \mathrm{~kg} \mathrm{~K} \mathrm{O}_{2}$

T4: 15.5 t compost $+90 \mathrm{~kg} \mathrm{~N}+38 \mathrm{~kg} \mathrm{P}_{2} \mathrm{O}_{5}+$ $38 \mathrm{~kg} \mathrm{~K} \mathrm{O}_{2}$

T5: 15.5 t compost $+60 \mathrm{~kg} \mathrm{~N}+38 \mathrm{~kg} \mathrm{P}_{2} \mathrm{O}_{5}+$ $38 \mathrm{~kg} \mathrm{~K}_{2} \mathrm{O}$ 
T6: 18.5 t compost $+90 \mathrm{~kg} \mathrm{~N}+38 \mathrm{~kg} \mathrm{P}_{2} \mathrm{O}_{5}+$ $38 \mathrm{~kg} \mathrm{~K}_{2} \mathrm{O}$

T7: 18.5 t compost $+60 \mathrm{~kg} \mathrm{~N}+38 \mathrm{~kg} \mathrm{P}_{2} \mathrm{O}_{5}+$ $38 \mathrm{~kg} \mathrm{~K}_{2} \mathrm{O}$

\section{Artificial inoculation of fungal pathogens}

\section{Inoculum production}

\section{Preparation of rice grain inoculum}

A rice grain mixture (cv.ADT 36) consisting of $2 / 3$ filled grains and $1 / 3$ chaffy grains and weighing $30 \mathrm{~g}$ in a $100 \mathrm{ml}$ Erlenmeyer flask, alter overnight presoaking in fresh water. After autoclave sterilization at $151 \mathrm{~b}$ pressure for $2 \mathrm{~h}$, the flask was inoculated with a $9 \mathrm{~mm}$ disc of 10-day-old PDA culture of $R$. solani. They were incubated at $25 \pm 3^{\circ} \mathrm{C}$ for 15 days and then used for inoculation (Amin et al., 1974).

\section{Method of inoculation}

Inoculation was done at active tillering phase, for T. cucumeris. In case of T. cucumeris rice seedlings were artificially inoculated by inserting the single rice grain culture (15 dayold), being placed inside base of the sheath enclosing culm.

\section{Disease intensity}

Individual tillers were assessed at 3 day intervals for fungal disease infection on a 0-9 scale, using Standard Evaluation System for Rice Diseases (Anon., 1981).

\section{Results and Discussion}

\section{Disease intensity}

The results on the disease intensity of sheath blight due to the application of coir waste composted by L. connatus, P. sajor - caju and urea, at different levels are presented in table 1. Among the mushroom fungi, L. connatus treated coir waste and urea at all levels significantly reduced the intensity of sheath blight, when compared with $P$. sajor- caju.

The treatments coir waste compost ( $L$. connatus)@18.5 t + urea@60kg N/ha and composted coir waste (L. connatus) @ 15.5 t/ha + urea@60 kg N / ha were found superior and significantly reduced the intensity of sheath blight (Gr. 3.00 and 3.52), compared to the existing fertilizer recommendation of $12.5 \mathrm{t}$ composted $+120 \mathrm{~kg}$ $\mathrm{N} / \mathrm{ha}$, where maximum disease intensity of Gr. 9.75 (sheath blight).The other treatments were on par with existing recommendation.

The similar trend was also observed with $P$. sajor - caju. The above said best treatments also significantly reduced the disease intensity of sheath blight (Gr. 5.60 and 6.20). The earlier treatments not significantly reduced the disease intensity and on par with existing recommendation (Fig. 1).

It is well known that lignocellulosic crop residues are the most abundant naturally occurring polymers in the biosphere. Fungi are unique among microorganisms in that they secrete a variety of extracellular enzymes to degrade lignocellulosic materials.

Decomposition of lignocellulosic residues is rated as the most important event in the carbon cycle of the earth (Bennett and Faison, 1997). Efficient and controlled degradation of lignocellulosic materials by these fungi lead to a number of processes of great economic importance. Pleurotus spp. well known white rot basidiomycotina produce lignocellulolytic enzymes to degrade complex of lignocellulosic residues, make their use as an alternative method presently used to overcome and reduce environmental pollution. 
Table.1 Efficacy of coir waste compost on the intensity of sheath blight of rice (var. ADT 36)

\begin{tabular}{|c|l|c|c|}
\hline S. No. & Fertilizer doses (ha) & $*$ L. connatus & $*$ P. sajor-caju \\
\cline { 3 - 4 } & & Sheath blight & Sheath blight* \\
\hline 1. & $12.5 \mathrm{t}+120 \mathrm{~kg} \mathrm{~N}($ control $)$ & 7.75 & 8.50 \\
2. & $12.5 \mathrm{t}+90 \mathrm{~kg} \mathrm{~N}$ & 7.00 & 7.81 \\
3. & $12.5 \mathrm{t}+60 \mathrm{kgN}$ & 6.52 & 7.50 \\
4. & $15.5 \mathrm{t}+90 \mathrm{kgN}$ & 6.48 & 7.95 \\
5. & $15.5 \mathrm{t}+60 \mathrm{kgN}$ & 3.52 & 6.20 \\
6, & $18.5 \mathrm{t}+90 \mathrm{kgN}$ & 6.12 & 7.92 \\
7. & $18.5 \mathrm{t}+60 \mathrm{kgN}$ & 3.00 & 5.60 \\
\hline \multicolumn{2}{|c|}{} \\
\hline \multicolumn{2}{|c|}{ CD $(\mathbf{P}=\mathbf{0 . 0 5})$} & $\mathbf{1 . 7 4}$ & $\mathbf{1 . 6 0}$
\end{tabular}

Species

Treatment

Species $\mathrm{x}$ treatments

* Disease intensity on 0-9 scale
Sheath blight

0.03

0.02

0.04

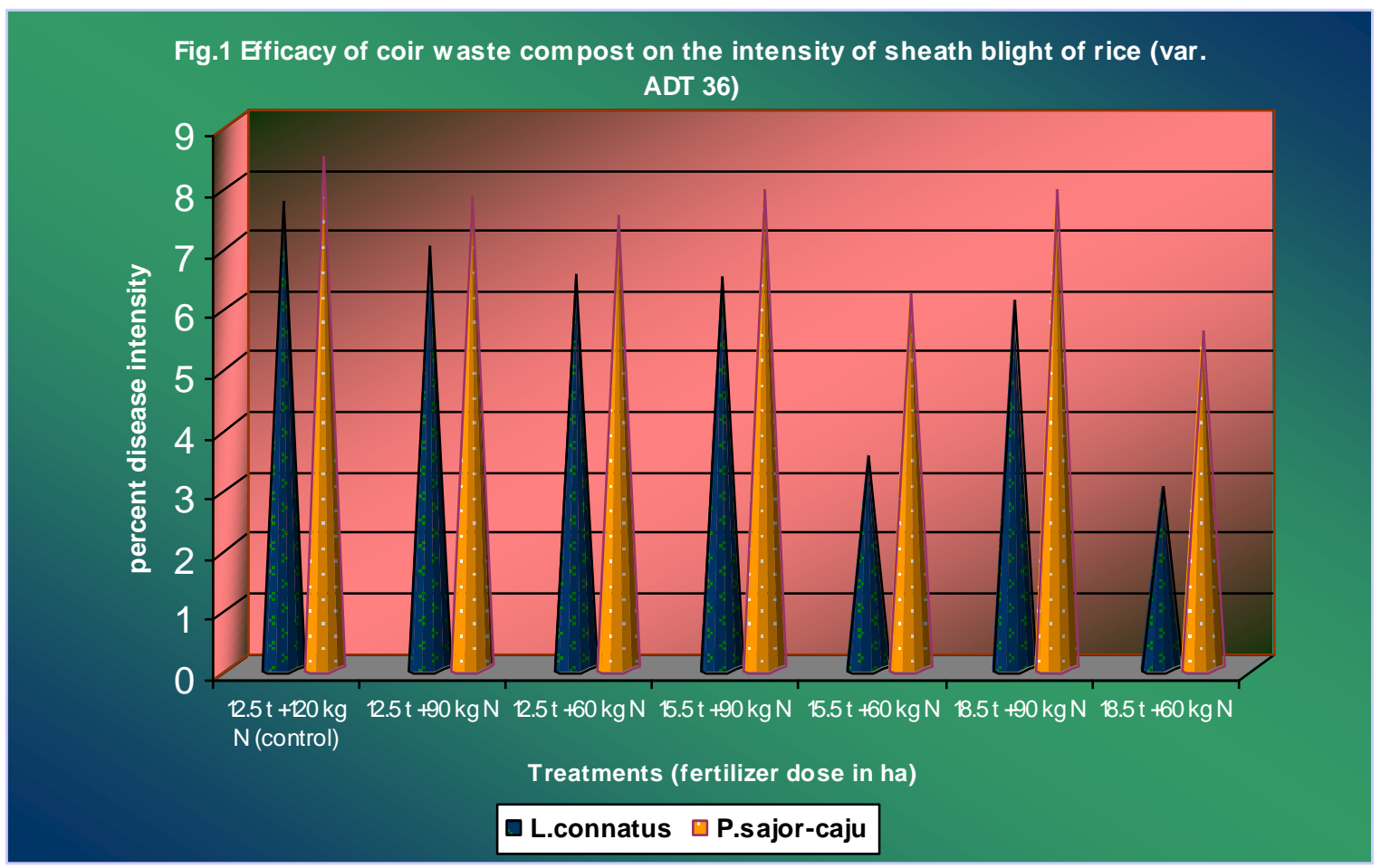

Coir waste compost on rice disease management

The current inorganic fertilizer prices and low availability of organic manure like farm yard manure, poultry manure etc., and their bulky need, limit the use of these available sources of nutrients in Agriculture. Use of coir waste, which is available in huge quantities, composted with mushroom fungi have been reported to improve the nutritional status of the soil and reduced various plant diseases (Rajan, 1980; Theradimani and Marimuthu 1992; Sheela, 1992). 
Increased in rice yield and significant reduction of major disease of rice by the application of 15.5 or $18.5 \mathrm{t}$ of coir compost (L. connatus) and urea at $60 \mathrm{~kg} \mathrm{~N}$ per ha, might be due to low inorganic nitrogen and high organic crop residue supplementation. Increased inorganic nitrogen appears to influence disease potential than inoculum potential and hence, high inorganic nitrogen level leads to the outbreak of fungal disease (Baker and Martinson, 1970). Conversely, organic residues at high level decrease disease intensity, even though the population of the pathogen is very high (Nash and Synder, 1962; Huber and Watson, 1974). Moreover incorporation of coir waste composted by $L$. connatus which contained high amount of minerals might also an important role in the reduction of diseases intensity and improvement of yield (Agrios, 1997)

Increased in rice yield and significant reduction of major disease of rice by the application of 15.5 or $18.5 \mathrm{t}$ of coir compost (L. connatus) and urea at $60 \mathrm{~kg} \mathrm{~N}$ per ha, might be due to low inorganic nitrogen and high organic crop residue supplementation. Increased inorganic nitrogen, appears to influence disease potential than inoculum potential and hence, high inorganic nitrogen level leads to the outbreak of fungal disease (Baker and Martinson, 1970). Conversely, organic residues at high level decrease disease intensity, even though the population of the pathogen is very high (Nash and synder, 1962; Huber and Watson, 1974). Moreover incorporation of coir waste composted by $L$ connatus which contained high amount of minerals, might also an important role in the reduction of diseases intensity and improvement of yield (Agrios, 1997).

\section{References}

Agrios, N., 1997. Environmental effects on the development of infectious plant disease. In: Plant Pathology. Academic Press, pp. 144-151.

Amin, K.S., B.D. Sharma, and C.R. Das 1974. Occurrence in India sheath rot of rice caused by Acrocylindrium oryzae. Pl. Dis. Reptr, 58: 358-360.

Anderson, D.C., A.T. Ralston, and J. Axelrod 1971. Chemical treatment of rye straw; in vitro dry matter digestibility and compositional changes. J Animal Sci., 37: 148-152.

Anonymous, 1981. Annual Report for 198081. Int. Rice. Instt, Philipines. 165-169.

Bannett, J.W., and B.D. Faison 1997. Use of fungi in Biodegradation. In: Environmental microbiology, AISM, press, Washington Pp. 310-313.

Beg, S., S.I. Zafan, and F.H. 1986. Shah Rice husk bio degradation by Pleurotus species to produce a ruminant feed. Agric wastes, 17: 15-21.

Huber, D.M., and R.D. 1974. Watson, Nitrogen form and Plant Disease, In: Journal Series of Purdue University Agricultural Experimental Station, West Lafyyette, Indiana. Pp. 139-165.

Lakshmanan, P., 2002. A new mushroom fungus identified in Tamil Nadu, Indian J. Pl. Diseases and Protection, (online).

Manickam, T.S., K. Seetharaman, K. Mayalagu and V. Mariappan 1980. Wealth from waste composted coir waste. Mushroom Res, 1: 45-47.

Marimuthu, T., 1995. Prospects of oyster mushroom in Tamil Nadu. J Eco. Biol, 7: 27-34

Nash, S.M., and W.C. Synder 1962. Quantitative estimation of plate counts of propagules of the bean root rot Fusarium in field soils. Phytopathology, 52: 567-572.

Piper, C.S., 1966. Soil and Plant analysis. Hanos Publishers, Bombay, P.368

Rajan, K.M., 1980. Soil amendments in plant disease control. IRRN, 5, 15

Sheeba, R.I, M.A. Nair and B.K. 
Jayachandran 1999. Organic recycling in coconut. Indian coconut J, 49:10-12

Sheela, J., 1992. Biological control of Fusarium wilt of Solanum melongena L. caused by Fasarium solani (Mart.) Sacc. M.Sc. (Ag.) Thesis, Tamil Nadu Agrl. Univ., Coimbatore, India. P.141.

Singh, M.P., and L.J. Griensven 2000. Biodegradation of lignocellulosic waste through cultivation of Pleurotus sajorcaju. Proc. $15^{\text {th }}$ Int. Cong. Sci. Culti. Edible Fungi, Maastricht, Netherlands, Pp. 617-618.

Theradimani, M., and T. Marimuthu 1992.
Utilization of Pleurotus spp. For decomposting coir pith. Mushroom Res., 1: 49-52.

Zadrazil, F., 1975. Influence of carbon dioxide concentration on the mycelial growth of three Pleurotus species. Eur $J$ Appl Microbio, 1: 327-335.

Zadrazil, F., 1984. Microbial conversion of lignocellulosic inti feed. In: straw and other fibrous by products as feed. (Eds. S. Sundstal and Owen). Development in Animal and Veterinary Sciences, 14: 276-292.

\section{How to cite this article:}

Sudha, A., M. Senthilkumar and Vijayakumar, M. 2017. Efficacy of Coir Waste Compost and Urea at Different Levels on the Incidence of Sheath Blight of Rice. Int.J.Curr.Microbiol.App.Sci. 6(9): 778-783. doi: https://doi.org/10.20546/ijcmas.2017.609.096 